\title{
KINERJA PENYULUH PERTANIAN LAPANGAN DALAM PENGEMBANGAN AGRIBISNIS JAGUNG SPESIFIK LOKASI DI KABUPATEN KUBU RAYA
}

\author{
HERU CHANDRA ${ }^{1)}$, ANI MUANI ${ }^{2)}$, KOMARIYATI ${ }^{2)}$ \\ 1) Alumni Magister Manajemen Agribisnis Fakultas Pertanian Universitas \\ Tanjungpura Pontianak. \\ ${ }^{2)}$ Staf Pengajar Fakultas Pertanian Universitas Tanjungpura Pontianak
}

\begin{abstract}
Agricultural extension workers have an important role in the development of agribusiness corn. This study aims to determine the performance of agricultural extension, the level of conformity of maize cultivation technology, analyze the relationship between the performance of the agricultural extension with maize cultivation technology specific location in Kubu Raya. The study population was a corn farmer in Sungai Raya and Rasau Jaya subdistrict, further sampling in this study is determined in proportion to the significance level of 10 percent of the population studied corn growers. The sampling method using the formula slovin. Analyzer used to measure the performance of agricultural extension field and the level of suitability of maize cultivation technology specific location using scoring techniques while to measure the relationship of closeness between them using the Spearman rank correlation analysis. The results showed that the performance of good agricultural extension category field, specifically maize cultivation technology locations lacking categorized in accordance with the advice and performance of agricultural extension field very real touch with the low category in maize cultivation technology specific.
\end{abstract}

Keywords: Performance, agricultural extension, adoption of technology, cultivation of corn, Specific locations

\section{PENDAHULUAN}

Penyuluhan pertanian lapangan memiliki peran yang sangat strategis karena penyuluh sebagai jembatan komunikasi antara pemerintah dengan petani terutama dalam mensukseskan program upaya khusus swasembada padi, jagung dan kedelai atau yang lebih dikenal dengan Program UpsusPajale yang harus dicapai dalam waktu 3 (tiga) tahun yaitu mulai tahun 2015 sampai dengan 2017. Strategi pencapaian swasembada berkelanjutan tersebut ditempuh dengan cara peningkatan produktivitas, perluasan areal tanam dan peningkatan indek pertanaman. Keberhasilan program upsus pajale khususnya komoditas jagung bergantung sejauhmana keterlibatan para penyuluh pertanian di lapangan.

Penyuluhan pertanian bagian dari sistem pembangunan pertanian yang merupakan pendidikan di luar sekolah (non formal) bagi petani beserta keluarganya dan anggota masyarakat lainnya yang terlibat dalam pembangunan pertanian, dengan demikian penyuluhan pertanian adalah suatu upaya untuk terciptanya iklim yang kondusif guna membantu petani beserta keluarga agar dapat berkembang menjadi dinamis serta mampu untuk memperbaiki kehidupannya dengan kekuatan sendiri dan pada akhirnya mampu menolong dirinya sendiri (Soeharto, N.P., 2015). Pengertian penyuluhan dalam Undang- 
undang No. 16 Tahun 2006 dijelaskan bahwa penyuluhan adalah proses pembelajaran bagi pelaku utama serta pelaku usaha agar mau dan mampu menolong dan mengorganisasikan dalam mengakses informasi informasi pasar, teknologi, permodalan dan sumber daya lainnya sebagai upaya untuk meningkatkan produktivitas, efisiensi usaha, pendapatan dan kesejahteraannya serta meningkatkan kesadaran dalam pelestarian fungsi lingkungan hidup.

Permintaan jagung baik untuk industri pangan, pakan, dan kebutuhan industri lainnya dalam lima tahun ke depan diproyeksikan akan terus meningkat seiring dengan terus bertambahnya jumlah penduduk.Menurut Kementerian Pertanian (2015)diperkirakan kebutuhan jagung untuk industri pakan ternak, konsumsi langsung, bahan baku industridan kebutuhan untuk benih akan mencapai lebih kurang 22 juta ton.

Kabupaten Kubu Raya satu diantara kabupaten yang ada di Kalimantan Barat dengan luas wilayah mencapai $6.985,24 \mathrm{~km}^{2}$ merupakan salah satu sentra penghasil komoditas jagung di Kalimantan Barat. Sebagian besar komoditas jagung di Kabupaten Kubu Raya diusahakan di lahan gambut yang memiliki karakteristik sifat fisik dan kimiawi tanah yang spesifik. Aplikasi teknologi spesifik lokasi lahan gambut harus mempertimbangkan dan memperhatikan sifat fisik dan kimiawi sebelum lahan gambut dimanfaatkan untuk budidaya jagung.Teknologi spesifik lokasi adalah sumber dayanya bisa berasal dari petani sendiri atau introduksi dari luar petani yang diinternalisasi secara terus-menerus sehingga menjadi kreativitas tani, memiliki daya adaptasi tinggi dengan kondisi agroekosistem dan sosial budaya setempat, mampu mengatasi permasalahan lokal, dan keluarannya lebih unggul daripada teknologi umum serta bertumpu pada kepentingan masyarakat setempat (Badan Litbang Pertanian, 2012).

Kondisi saat ini, berdasarkan Kalimantan Barat Dalam Angka Tahun 2015, produksi jagung Kabupaten Kubu Raya sebesar 11.588 ton jagung pipil kering atau sebesar 8,55 persen dari total produksi jagung Kalimantan Barat sebesar 135.461 ton, sedangkan kontribusi terbesar diberikan oleh Kabupaten Bengkayang yaitu sebesar 103.857 ton jagung pipil kering atau sebesar 76,66 persen. Ditinjau dari produktivitas, Kabupaten Kubu Raya hanya sebesar 29,10 kw/ha sedangkan Kabupaten Bengkayang sebesar 40,51 kw/ha, ha ini menunjukkan adanya kendala dalam pengembangan agribisnis jagung khususnya subsistem produksi seperti penerapan teknologi spesifik lokasi.

Rendahnya produktivitas jagung di Kabupaten Kubu Raya tidak terlepas dari kendala di subsistem produksi yaitu penerapan teknologi budidaya jagung spesifik lokasi yang tidak optimal, diantaranya adalah : (a) Persiapan lahan seadanya (b) belum menggunakan varietas unggul baru dan benih bermutu; (c) pengaturan jarak tanam tidak teratur; (d) pemupukan tidak dilakukan atau seadanya saja tergantung kemampuan; (e) pengelolaan air tidak efisien; (f) pengendalian hama dan penyakit; (g) penanganan panen dan pascapanen.Rendahnya produktivitas usahatani jagung tersebut selain dipengaruhi oleh subsistem produksi, diduga berhubungan dengan kinerja penyuluh pertanian lapangan yang belum maksimal dalam penerapan teknologi spesifik lokasi. Upaya penerapan teknologi budidaya jagung spesifik lokasi dalam meningkatkan produktivitas di daerah ini diperlukan penyuluh pertanian yang mampu merubah prilaku, keterampilan dan sikap petani dalam mengelola usahataninya.

Data SIMPP (Sistem Informasi Manajemen Penyuluhan Pertanian 
Kementerian Pertanian)Tahun 2016, terdapat 53 orangpenyuluh PNS dan20 orang penyuluh THL-TB (Tenaga Harian LepasTenaga Bantu) yang tersebar di 9 Kecamatan di Kabupaten Kubu Raya sedangkan jumlah desa yang ada di Kabupaten Kubu Raya sebanyak 123 desa, artinya jumlah penyuluh pertanian tidak berbanding lurus dengan jumlah desa yang ada, kondisi ini tidak sejalan dengan kebijakan Kementerian Pertanian yang menetapkan satu desa satu penyuluh pertanian, sehingga di Kabupaten Kubu Raya masih kekurangan 50 penyuluh pertanian lapangan.

Agribisnis adalah suatu kesatuan sistem yang terdiri dari beberapa subsistem yang saling terkait erat, yaitu subsistem pengadaan dan penyaluran sarana produksi, subsistem usahatani atau produksi, subsistem pengolahan, subsistem pemasaran, serta subsistem jasa dan penunjang (Badan Agribisnis, 1995). Menurut Soekartawi (2001) Agribisnis merupakan suatu kegiatan yang utuh dan tidak dapat terpisah antara satu kegiatan dan kegiatan lainnya, mulai dari proses produksi, pengolahan hasil, pemasaran dan aktifitas lain yang berkaitan dengan kegiatan pertanian. Dalam arti luas agribisnis adalah berbagai aktivitas yang mendukung kegiatan pertanian.

Pengembangan agribisnis jagung di Kabupaten Raya dalam upaya peningkatan produktivitas masih terkendala dalam subsistem produksi yaitu penerapan teknologi spesifik lokasi secara penuh dan utuh di tingkat petani jagung yang dindikasikan dari produktivitas jagung yang rendah hanya berkisar 29,10 $\mathrm{kw} / \mathrm{ha}$.

Tulisan ini bertujuan untuk: 1) Mengetahui kinerja penyuluh pertanian lapangan dalam pengembangan agribisnis jagung spesifik lokasi di Kabupaten Kubu Raya; 2) Mengetahui tingkat penerapan teknologi budidaya jagung spesifik lokasi di Kabupaten Kubu Raya; 3) Mengetahui hubungan kinerja penyuluh pertanianlapangan dengan tingkat penerapan teknologi budidaya jagung spesifik lokasi di Kabupaten Kubu Raya.

\section{METODE PENELITIAN}

\section{Deskripsi dan Indikator Kinerja}

Pengertian kinerja adalah hasil kerja atau prestasi kerja yang dapat dicapai oleh seseorang atau kelompok orang dalam suatu perusahaan sesuai dengan wewenang dan tanggung jawab masing-masing dalam upaya pencapaian tujuan perusahaan secara legal, tidak melanggar hukum dan tidak bertentangan dengan moral dan etika (Rahadi, 2010), sedangkan Kementerian Pertanian (2013)menjelaskanpenilaiankinerja penyuluh pertanian adalah suatu kegiatan yang dilaksanakan secara sistematis dan berkesinambungan untuk mengukur tingkat keberhasilan berdasarkan parameter kinerja Penyuluh Pertanian dalam melaksanakan tugas dan tanggungjawabnya.

Indikator penilaian kinerja penyuluh pertanian diukur berdasarkan dari tugas pokok penyuluh pertanian yaitu: a) Persiapan penyuluhan pertanian; b) Pelaksanaan penyuluhan pertanian; dan c) Evaluasi dan pelaporan penyuluhan pertanian.

\section{Lokasi Penelitian dan Jumlah Sampe}

Pemilihan lokasi ini ditentukan dengan menggunakan metode purposivesampling yaitu suatu metode penentuan lokasi/sampel penelitian yang didasarkanatas pertimbangan-pertimbangan tertentu (Hadi, 1988). Pertimbangan- 
pertimbangan dalam penentuan lokasi penelitian didasarkan antara lain: (a) keragaman populasi; (b) ketersediaan tenaga, waktu dan biaya. Dalam hal ini lokasi penelitian yang dipilih yaitu Kecamatan Sungai Raya dan Kecamatan Rasau Jaya Kabupaten Kubu Raya dengan pertimbangan adalah daerah tersebut merupakan daerah sentral produksi jagungdi Kabupaten Kubu Raya dan mudah dijangkau oleh peneliti.

Populasi penelitian ini adalah petani jagung di Kecamatan Sungai Raya dan Kecamatan Rasau Jaya, selanjutnya pengambilan sampel dalam penelitian ini ditentukan secara proporsional dengan taraf signifikansi 10 persen dari populasi petani jagung yang diteliti. Jumlah sampel ditentukan berdasarkan rumus Slovin (Consuelo, 1993).

$$
k 1 \quad S \quad: \quad n=\frac{N}{1+N u^{2}}
$$

dimana

$$
\begin{array}{lll}
\mathrm{n} & = & \text { Besar Sampel } \\
\mathrm{N} & = & \text { Besar Populasi } \\
\alpha & = & \text { Batas Toleransi Kesalahan (error tolerance) }
\end{array}
$$

Berdasarkan data BPS Kabupaten Kubu Raya (2015), jumlah rumah tangga petani jagung untuk Kecamatan Sungai Raya berjumlah 1.677 rumah tangga tani dan Kecamatan Rasau Jaya berjumlah 428 rumah tangga tani, jadi total populasi sebanyak $1.677+428=2.105$. Berdasarkan rumus Slovin, maka reponden untuk petani jagung adalah:

$$
\begin{aligned}
\text { Rumus Slovin: } \mathrm{n}= & \frac{\mathrm{N}}{1+\mathrm{N} \alpha^{2}} \\
& \frac{2.105}{1+2.105(10 \%)^{2}} \\
& \frac{2.105}{1+2.105(0,01)}=95,464 \approx 95
\end{aligned}
$$

\section{Pengukuran kinerjapenyuluh pertanian}

Variabel kinerja penyuluh pertanian lapangan yang akan diteliti meliputi:

1. Persiapan penyuluhan pertanian dengan indikator-indikator: a). Membuat data potensi wilayah dan agro ekosistem; b). Memandu (pengawalan dan pendampingan) penyusunan Rencana definitif kebutuhan kelompok (RDKK); c). Penyusunan programa penyuluhan pertanian desa dan kecamatan; d). Membuat Rencana Kerja Tahunan Penyuluh Pertanian (RKTPP).

2. Pelaksanaan Penyuluhan Pertanian dengan indikator-indikator : a). Melaksanakan desiminasi/penyebaran materi penyuluhan sesuai kebutuhan petani; b). Melaksanakan penerapan metoda penyuluhan pertanian di wilayah binaan; c). Melakukan peningkatan kapasitas petani terhadap akses informasi pasar, teknologi, sarana prasarana, dan pembiayaan; d). Menumbuhkan dan mengembangkan kelembagaan petani dari aspek kuantitas dan kualitas; e). Menumbuhkan dan mengembangkan kelembagaan ekonomi petani dari aspek kuantitas dan kualitas; f). Meningkatnya produktivitas. 
3. Evaluasi dan Pelaporan Penyuluhan Pertanian dengan indikator-indikator : a).Melakukan evaluasi pelaksanaan penyuluhan pertanian; b). Membuat laporan pelaksanaan penyuluhan pertanian.

\section{Pengukuran penerapan teknologi budidaya jagung spesifik lokasi}

Penerapan teknologi spesifik lokasi dalam budidaya tanaman bertujuan untuk menyesuaikan diri terhadap lingkungan tumbuh sehingga diperoleh pertumbuhan dan hasil yang optimal. Cara budidaya pun perlu disesuaikan karena kondisi lingkungan dan varietas yang digunakan juga berbeda antarlokasi. Sebagian besar permasalahan dalam peningkatan hasil disebabkan oleh penerapan teknologi yang tidak tepat (Utami, et al., 2016). Penerapan teknologi budidaya jagung oleh petani,pada umumnya masih bersifat parsial khususnya bagi wilayah berproduktivitasrendah. Memperpadukan sejumlah komponen teknologi produksi diharapkan akanmeningkatkan produktivitas dan pendapatan usahatani jagung(Departemen Pertanian, 2008).

Variabel yang diteliti dalam penelitian ini adalah kesesuaian penerapan teknologi budidaya jagung spesifik lokasi yang diukur dari penyiapan lahan, pemilihan benih, penanaman, pengelolaan air, pemupukan, pengendalian gulma dan pembumbunan, pemberantasan hama dan penyakit, panen dan pasca panen.

\section{Analisis Data}

\section{Penilaian kinerja penyuluh pertanian}

Kinerja penyuluh pertanian di Kabupaten Kubu Rayadiukur dengan standar nilai prestasi kerja (NPK) dengan metode teknik skoring, adapun langkahlangkahnya adalah sebagai berikut:

1. Jumlah parameter sebanyak 16 , setiap indikator dinilai dengan mengggunakan skala 1 sampai dengan 5. Skala 1 menunjukkan kinerja buruk, skala 2 menunjukkan kinerja kurang baik, skala 3 menunjukkan kinerja cukup baik, skala 4 menunjukkan kinerja baik dan skala 5 menunjukan kinerja paling tinggi yaitu sangat baik. Jumlah nilai seluruh pengukuran/parameter yaitu paling rendah 16 (jumlah pengukuran/parameter $=16 \mathrm{X} 1$ ) dan paling tinggi 80 (jumlah pengukuran/parameter $=16 \mathrm{X} 5$ ).

2. Standar NPK penyuluh pertanian lapangan dinyatakan dalam angka dan sebutan seperti tabel 1 berikut:

Tabel 1. Standar NPK Penyuluh Pertanian Lapangan

\begin{tabular}{ccc}
\hline No & Nilai & Prestasi Kerja \\
\hline 1 & 91 keatas & Sangat Baik \\
2 & $76-90$ & Baik \\
3 & $61-75$ & Cukup Baik \\
4 & $51-60$ & Kurang Baik \\
5 & 50 ke bawah & Buruk \\
\hline
\end{tabular}

3. Tata Cara Perhitungan :

$$
\text { NPK }=\frac{\text { Total Skor }}{80} \times 100
$$

\section{Penilaianpenerapanteknologi}

Tingkat kesesuaian penerapan teknologi budidaya jagung spesifik lokasi di

Kabupaten Kubu Rayayang telah dianjurkan diukur dengan standar nilai kesesuaian penerapan (NKP) dengan langkah sebagai berikut:

1. Jumlah parameter sebanyak 13, setiap indikator dinilai dengan mengggunakan skala 1 sampai dengan 5 yang menunjukkan tingkat kesuaian penerapan 
teknologi budidaya jagung spesifik lokasi. Skala 1 menunjukkan penerapan teknologi sangat tidak sesuai, skala 2 menunjukkan penerapan teknologi kurang sesuai, skala 3 menunjukkan penerapan teknologi cukup sesuai, skala 4 menunjukkan penerapan teknologi sesuai dan skala 5 menunjukkan penerapan teknologi sangat sesuai. Jumlah nilai seluruh pengukuran/parameter yaitu paling rendah 13 (13 X 1) dan paling tinggi 65 (13 X 5).

2. Penentuan skor secara agregat dengan menggunakan rumus Interval kelas,dengan rumus sebagai berikut:

3. Penentuan skor untuk setiap parameter dengan menggunakan rumus Interval kelas,dengan rumus sebagai berikut:

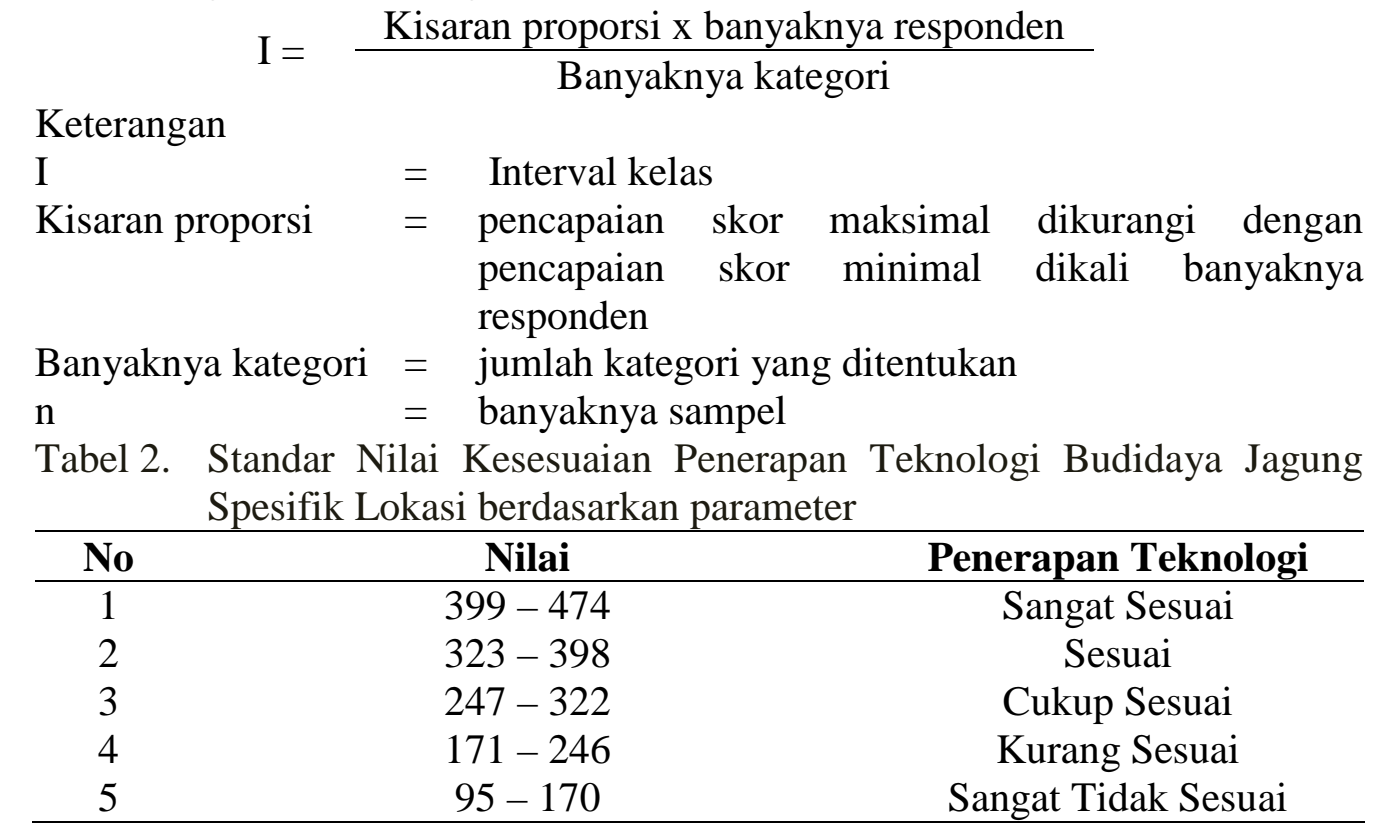

Analisis korelasi jenjang spearman

Untuk menjawab apakah kinerja penyuluh pertanian memiliki hubungan dalam penerapan teknologi budidaya jagung spesifik lokasi maka dianalisis melalui uji koefisien korelasi rank Spearman.Korelasi rank Spearman biasa juga disebut korelasi berjenjang $\left(\mathrm{r}_{\mathrm{s}}\right)$ kegunaannya adalah untuk mengukur tingkat keeratan hubungan antara dua variabel atau variabel bebas dengan variabel terikat yang berskala ordinal (Riduwan, 2010). Rumus korelasi jenjang Spearman yang digunakan yaitu:

Keterangan:

$$
r_{\mathrm{s}}=1-\frac{6 \sum_{\mathrm{l}=1}^{\mathrm{N}} \mathrm{d}_{\mathrm{i}}^{2}}{\mathrm{n}\left(\mathrm{n}^{2}-1\right)}
$$

$\mathrm{r}_{\mathrm{s}}=$ Nilai korelasi jenjang Spearman

$\mathrm{d}=$ Selisih setiap pasang jenjang

$\mathrm{n}=$ Jumlah sampel penelitian

Menurut (Sugiyono, 2007)pedoman untuk memberikan interpretasi koefisien korelasi sebagai berikut: 


\begin{tabular}{ccc}
\hline Koefisien & Kekuatan Hubungan \\
\hline 0,00 & $-0,199$ & sangat rendah \\
0,20 & $-0,399$ & Rendah \\
0,40 & $-0,599$ & Sedang \\
0,60 & $-0,799$ & Kuat \\
0,80 & $-1,000$ & sangat kuat \\
\hline
\end{tabular}

\section{HASIL DAN PEMBAHASAN}

Berdasarkan hasil pengukuran kinerja penyuluh pertanian lapangan yang terdiri dari 16 parameter dengan teknik skoring secara keseluruhan dapat dillihat pada tabel dibawah ini :

Tabel 3. Nilai Prestasi Kerja Penyuluh Pertanian Lapangan BerdasarkanParameter Pengukuran

\begin{tabular}{clcc}
\hline No. & \multicolumn{1}{c}{ Parameter Pengukuran } & NPK & Kategori \\
\hline 1 & Membuat data potensi wilayah dan agro ekosistem & 96,00 & Sangat baik \\
2 & Memandu penyusunan RDKK & 84,84 & Baik \\
3 & Penyusunan programa penyuluhan pertanian & 96,00 & Sangat baik \\
4 & Membuat rencana kerja tahunan penyuluh pertanian & 96,00 & Sangat baik \\
5 & Melaksanakan desiminasi/penyebaran materi penyuluhan & 80,84 & Baik \\
6 & Melaksanakan kunjungan / tatap muka & 88,42 & Baik \\
7 & Melaksanakan Demontrasi penyuluhan pertanian & 69,68 & Cukup Baik \\
8 & Melaksanakan pertemuan penyuluhan & 68,42 & Cukup Baik \\
9 & Melaksanakan kursus tani & 52,00 & Kurang Baik \\
10 & Peningkatan kapasitas petani terhadap akses informasi & 96,00 & Sangat baik \\
11 & Menumbuhkan kelompoktani/gapoktan & 76,92 & Baik \\
12 & Meningkatkan kelas kelompoktani & 72,00 & Cukup Baik \\
13 & Menumbuhkan dan mengembangkan KEP & 24,84 & Buruk \\
14 & Meningkatnya produksi komoditi unggulan di WKPP & 76,00 & Baik \\
15 & Melakukan evaluasi pelaksanaan penyuluhan pertanian & 84,84 & Baik \\
16 & Membuat laporan pelaksanaan penyuluhan pertanian & 96,00 & Sangat baik \\
\hline & & $\mathbf{7 8 , 6 7}$ & Baik \\
\hline
\end{tabular}

Sumber : Analisis data primer (data diolah), 2016

Hasil penelitian secara agregat menunjukkan bahwa kinerja penyuluhpertanian lapangan berkategori baik dengan rata-rata nilai prestasi kerja sebesar 78,67, namun dari variabel pelaksanaan penyuluhan ada yang berkategori kurang baik bahkan berkategori buruk yaitu pelaksanaan kursus tani dan menumbuhkan dan mengembangkan KEP. Kegiatan kursus tani dalam penelitian ini berkategori kurang baik dengan skor 52,00 artinya pelaksanaan kursus tani dilakukan sekali dalam satu tahun dan kegiatan menumbuhkan dan mengembangkan kelembagaan ekonomi petani berkategori buruk dengan skor 24,84artinya PPL hanya memfasilitasi kelembagaan ekonomi petani dalam bentuk koperasi tani belum berbadan hukum. Terkait dengan pelaksanaan kursus tani yang berkategori kurang baik penyebabnyaantara lain adalah pelaksanaan kursus tani relatif mahal, memerlukan perencanaan yangmatang, memerlukan sarana dan alat bantu proses pembelajaran. Disisi lain PPL lebih senang menggunakan metode kunjungan/tatap muka dalam proses pembelajaran kepada petani karena metode ini biayanya lebih murah dan tujuan lebih mudah tercapai. Sedangkan kegiatan menumbuhkan dan mengembangkan kelembagaan ekonomi petani berkategori buruk diantaranya adalah tidak tersedianya tenaga untuk mengelola kelembagaan ekonomi petani selain itu ketersediaan dana juga menjadi 
permasalahan karena membuat akte pendirian KEP ke notaris memerlukan biaya cukup besar serta biaya-biaya lain yang ditimbulkan dalam pengurusan akte tersebut. Penyuluh pertanian lapangan harus membenahi parameter yang berada di kategori kurang baik dan buruk, yaitu pelaksanaan kegiatan kursus tani dan menumbuhkembangkan kelembagaan ekonomi petani.

Berdasarkan hasil pengukuran tingkat kesesuaian penerapan teknologi budidaya jagung spesifik lokasi yang terdiri dari 13 parameter dengan teknik skoring secara keseluruhan dapat dillihat pada tabel dibawah ini :

Tabel 4. Skor Tingkat Kesesuaian Penerapan TeknologiBudidaya Jagung Spesifik Lokasi

\begin{tabular}{clcc}
\hline No & \multicolumn{1}{c}{ Penerapan Teknologi } & Total Skor & Kategori \\
\hline 1 & Pengolahan Lahan & 271 & Cukup Sesuai \\
2 & Pengapuran Lahan & 250 & Cukup Sesuai \\
3 & Pemilihan Benih & 309 & Cukup Sesuai \\
4 & Penanaman & 386 & Sesuai \\
5 & Pembuatan saluran drainase/irigasi & 161 & Tidak Sesuai \\
6 & Waktu pemberian air & 149 & Tidak Sesuai \\
7 & Pemberian pupuk kima/anorganik & 161 & Tidak Sesuai \\
8 & Pemberian pupuk organik sesuai dosis & 195 & Kurang Sesuai \\
9 & Teknis pengendalian gulma dan pembumbumban & 149 & Tidak Sesuai \\
10 & Pengendalian hama secara terpadu & 201 & Kurang Sesuai \\
11 & Pengendalian penyakit & 196 & Kurang Sesuai \\
12 & Penanganan panen & 386 & Sesuai \\
13 & Penanganan Pasca panen & 352 & Sesuai \\
\hline & & $\mathbf{3 . 1 6 6}$ & - \\
\hline Kesesuaian & Petani Dalam Penerapan Teknologi $\mathbf{3 . 1 6 6 ~ : ~ 9 5 = 3 3 , 3 3 ~ ) ~}$ & $\mathbf{3 3 , 3 3}$ & Kurang sesuai \\
\hline
\end{tabular}

Sumber : Analisis data primer (data diolah), 2016

Hasil penelitian secara keseluruhanmenunjukkan bahwa penerapan teknologi budidaya jagung spesifik lokasi berkategori kurang sesuai dengan ratarata nilai sebesar 33,33 namun dari variabel pengukuran ada yang berkategori sesuai yaitu penentuan jarak tanam, penanganan panen dan pasca panen.Hasil wawancara dengan petani didapati beberapa temuan penyebab kurang sesuainya penerapan teknologi budidaya jagung spesifik lokasi di Kabupaten Kubu Raya dengan yang dianjurkan antara lainadalah :

a. Petani jagung di Kabupaten Kubu Raya lebih senang menggunakan benih lokal karena jagung juga digunakan sebagai makanan sehari-hari yang dicampur dengan nasi dan rasanya lebih enak;

b. Benih lokal lebih mudah diperoleh karena tidak perlu membeli yaitu dengan menyisakan hasil panen untuk keperluan benih dan harga benih hibrida relatif mahal. Disisi lain, harga jual produksi jagung lokal lebih tinggi (Rp. $100 \mathrm{~s} / \mathrm{d}$ Rp. 300) dari jagung hibrida;

c. Budidaya jagung dengan benih lokal lebih mudah dalam pemeliharaannya baik dari sisi pemberian pupuk organik, pengendalian hama, pengendalian penyakit, pengelolaan air, penggunaan pupuk kimia dan pengendalian gulma;

d. Umumnya petani jagung pada proses pengolahan lahan hanya melakukan tebas tebang, semprot herbisida dan langsung tanam, sehingga tidak 
melakukan pembuatan saluran drainase. Cara ini memang lebih murah, tidak memerlukan tenaga kerja yang banyak, namun kalau intensitas curah hujan meningkat maka lahan usaha tani jagung dapat terendam yang dapat menyebabkan pertumbuhan tanaman jagung tidak optimal bahkan dapat menyebabkan kematian;

e. Usahatani jagung di Kabupaten Kubu Raya hingga saat ini masih bergantung pada air hujan sehingga pengelolaan air tidak optimal yaitu tepat waktu, tepat jumlah, dan tepat sasaran, sehingga tidak efisien dalam upaya peningkatan produktivitas.

f. Terkait pemberian pupuk, petani jagung di Kabupaten Kubu Raya umumnya hanya memberikan pupuk urea seadanya dengan dosis rata-rata $50 \mathrm{~kg}$ per hektar dan hanya sedikit memberikan pupuk organik (pupuk kandang). Penyebab tidak tepatnya penerapan teknologi pemupukan pada usahatani jagung adalah keterbatasan petani hal permodalan sehingga pemberian pupuk hanya tergantung pada saat petani memiliki uang;

g. Terkait dengan pengendalian hama terpadu, petani di Kabupaten Kubu Raya tidak melakukan langkah-langkah pengendalian hama terpadu sesuai anjuran seperti pergiliran tanaman untuk memutus siklus hidup hama, pengendalian dengan musuh alami, perlakuan benih atau seed treatment, pengendalian mekanik. Petani hanya melakukan pengendalian hama dengan cara pengendalian kimiawi. Hal ini dilakukan karena cara ini termasuk murah dalam usahatani jagung;

h. Terkait dengan pengendalian penyakit terpadu, petani di Kabupaten Kubu Raya tidak melakukan langkah-langka pengendalian hama terpadu sesuai anjuran sepertisanitasi dan eradikasi yaitu dengan melakukan pencabutan tanaman yang terserang teknik bercocok tanam seperti menjaga kelembaban areal tanam, perlakuan benih dengan menggunakan fungisida secara merata. Petani hanya melakukan dengan menanam varietas tahan penyakit (benih lokal) dan melakukan pengendalian dengan cara kimiawi (fungisida).

Sejalan dengan pendapat ahli Rogers (2003), menerima atau menolak suatu inovasi adalah keputusan yang dibuatoleh seseorang setelah mengetahui dan mempelajari suatu inovasi baru. Petani umumnya memahami bahwa penerapan teknologi budidaya jagung spesifik lokasi dapat meningkatkan produksi persatuan luas, namun karakteristik inovasi seperti, keuntungan relatif, kesesuaian dengan nilai-nilai budaya yang ada dan kompleksitas inovasi itu sendiri sangat mempengaruhi adopsi teknologi di tingkat petani.

\section{AnalisisHubunganKinerja PPL denganPenerapan Teknologi}

Hasil analisis dengan SPSS.16 for windows menunjukkan koefisien korelasi antara X (kinerja PPL) dan variabel Y (penerapan teknologi) adalah sebesar 0,345 dengan arah positif. Halini mengindikasikanperubahan kinerja PPL akan diikutisecara positip oleh tingkat kesesuaian penerapan teknologi budidaya jagung spesifik lokasi oleh petani. Hubungan antara keduavariabel tersebut sangat signifikan yang ditunjukkan nilai P atau Sig. sebesar 0,001 (1\%) dan tandabintang dua ** menunjukkan hubungan kedua variabel tersebutsangat signifikan. Angka koefisien korelasi sebesar 0,345 menunjukkan hubungan antara kinerja penyuluh pertanian lapangan dengan penerapan teknologi budidaya jagung spesifik lokasi termasuk rendah (masuk kisaran koefisien 0,20 - 0,399). Kekuatan hubungan 
berkategori rendah mengacu (Sugiyono, 2007) tentang pedoman untuk memberikan interpretasi koefisien korelasi.

\section{KESIMPULAN DAN SARAN Kesimpulan}

Berdasarkan pemaparan permasalahan, tujuan, hasil penelitian dan pembahasan pada bab-bab sebelumnya, kinerja penyuluh pertanian lapangan dalam pengembangan agribisnis jagung spesifik lokasi di Kabupaten Kubu Rayasecara agregat termasuk dalam kategori baik. Pelaksanaan kursus tani berkategori kurang baik (kategori kurang baik dimaksud adalah pelaksanaan kegiatan kursus tani dilakukan hanya satu kali dalam satu tahun terakhir, bukan berarti kegiatan kursus tani tidak pernah dilaksanakan sama sekali) satu diantara penyebabnyaadalah pelaksanaan kursus tani relatif mahal, memerlukan perencanaan yang matang, memerlukan sarana dan alat bantu proses pembelajaran. Disisi lain PPL lebih senang menggunakan metode penyuluhan dengan kunjungan/tatap muka dalam proses pembelajaran kepada petani karena metode ini biayanya lebih murah dan tujuan lebih mudah tercapai.Berkenaan kinerja menumbuhkan dan mengembangkan kelembagaan ekonomi petani (KEP)berkategori buruk (kategori buruk dimaksud adalah penyuluh memfasilitasi BUMP yang berbentuk koperasi tani namun belum berbadan hukum)disebabkan antara lain adalah a). Minimnya ketersediaan tenaga untuk mengelola kelembagaan ekonomi petani; b). Kurangnya dana untuk pengurusan akte pendirian ke notaris dan biaya-biaya lain yang ditimbulkan dalam pengurusan tersebut.

Tingkat penerapan teknologi budidaya jagung spesifik lokasi di Kabupaten Kubu Raya termasuk dalam kategori kurang sesuai dengan yang telah dianjurkan oleh PPL. Ketidaksesuaian penerapan teknologi dengan yang dianjurkan PPL bukan dikarenakan ketidaktahuan petani melainkan namun disebabkan karakteristik inovasi, seperti keuntungan relatif, kesesuaian dengan nilai-nilai budaya yang ada dan kompleksitas inovasi itu sendiri sangat mempengaruhi adopsi teknologi di tingkat petani, selain itu keterbatasan petani dalam hal permodalan sehingga tidak mampu membiayai usahataninya.

Kinerja PPL berhubungan sangat nyata dengan tingkat penerapan teknologi budidaya jagung spesifik lokasi. Nilai koefisien adalah sebesar 0,345 (arah positif) menjelaskan perubahan kinerja PPL akan diikuti secara positip oleh penerapan teknologi budidaya jagung spesifik lokasi oleh petani. Namun kekuatan hubungan termasuk kategori rendah karena nilai koefisien korelasi sebesar 0,345 termasuk dalam kisaran 0,20 - 0,399. Penyebab rendahnya kekuatan hubungan tersebut adalah petani tidak sesuai menerapkan teknologi budidaya jagung spesifik lokasi yang dianjurkan oleh PPL.

\section{Saran}

Kinerja penyuluh pertanian lapangan sangat penting dalam pengembangan subsistem produksi khususnya penerapan teknologi budidaya jagung spesifik lokasi. Berdasarkan hasil penelitian ini, pelaksanaan kursus tani masih berkategori kurang baik, oleh karena itu disarankan penyuluh pertanian lapangan perlu meningkatkan metode penyuluhan pertanian dalam bentuk kursus tani agar pengetahuan dan keterampilan petani menjadi lebih baik.

Kegiatan penumbuhan dan pengembangan kelembagaan ekonomi petani 
merupakan terobosan dalam rangka mengembangkan kegitan penyuluhan pertanian. Berdasarkan hasil penelitian ini, pelaksanaan menumbuhkan dan mengembangkan kelembagaan ekonomi petani kursus tani masih berkategori buruk, oleh karena itu diharapkan penyuluh pertanian lapangan mampu menumbuhkan dan mengembangkan kelembagaan ekonomi petani agar diperoleh kelembagaan petani yang mandiri, meningkat skala ekonominya dan efisien dalam berusahatani. Penyuluh pertanian lapangan diharapkan dapat berkoordinasi dengan instansi yang menangani koperasi dan usaha kecil menengah di Kabupaten Kubu Raya agar dapat memfasilitasi pembentukan kelembagaan ekonomi petani.

Perlu adanya penelitian lanjutan khususnya berkaitan faktor-faktor yang mempengaruhi rendahnya penerapan teknologi budidaya jagung spesifik lokasi di Kabupaten Kubu Raya.

\section{DAFTAR PUSTAKA}

Badan Litbang Pertanian. 2012.Kemandirian Pangan Indonesia Dalam Perspektif Kebijakan MP3EI. Jakarta : Badan Litbang Pertanian.

BPS Kabupaten Kubu Raya. 2015.Kubu Raya Dalam Angka 2015. Kubu Raya : Badan Pusat Statistik Kabupaten Kubu Raya.

Departemen Pertanian. 2008.Pedoman Pengelolaan Tanaman Terpadu Budidaya Jagung. Jakarta : Departemen Pertanian.

Kementerian Pertanian. 2013.Evaluasi Kinerja Penyuluhan. Jakarta : Kementerian Pertanian.

-. 2015.Pedoman Pelaksanaan GP-PTT. Jakarta : Kementerian Pertanian.

-. 2016.Sistem Informasi Manajemen Penyuluhan Pertanian. Jakarta: Kementerian Pertanian.

Mangkunegara, Anwar Prabu. 2005.Evaluasi Kinerja Sumber Daya Manusia. Bandung : PT. Refika Aditama.

Rahadi, Dedi Rianto. 2010.Manajemen Kinerja Sumber Daya Manusia. Malang : Tunggal Mandiri Publishing.

Rogers, EM. 2003. Diffusion of Innovation. Fifth Edition.New York: The Free Press.

Soeharto, N.P. 2015.Programa Penyuluhan Pertanian (Materi dalam diklat penyuluhan dasar-dasar fungsional penyuluh). Jakarta.

Soekartawi.2001. Analisis Usahatani. UI Press. Jakarta.

Sugiyono. 2007.Metode Penelitian Pendidikan Pendekatan Kuantitatif, Kualitatif, dan $R \& D$. Bandung : Alfabeta.

Undang-Undang Republik Indonesia Nomor 16 Tahun 2006.Sistem Penyuluhan Pertanian, Perikanan, dan Kehutanan. Jakarta.

Utami, Sri Nuryani Hidayah, Priyatmojo, Achmadi dan Subejo. 2016.Penerapan Teknologi Tepat Guna Padi Sawah Spesifik Lokasi di Dusun Ponggok, Trimulyo, Jetis, Bantul. Yogyakarta : Indonesian Journal of Community Engagement Vol. 01, No. 02, Maret 2016. 